Borneo Journal of Sciences and Technology, Volume (1), Issue (2), Pages: 62-68

DOI: https://doi.org/10.35370/bjost.2019.1.2-09

e-ISSN: 2672-7439

(C) 2019, UCTS Publisher.

$\begin{array}{lll}\text { Submitted: } 9^{\text {th }} \text { March } 2019 & \text { Accepted: } 30^{\text {th }} \text { March } 2019 & \text { Published: } 31^{\text {st }} \text { July } 2019\end{array}$

\title{
Antioxidants and Phytochemical Analysis of Endophytic Fungi Isolated from a Medicinal Plant Catharanthus roseus
}

\author{
Farah Wahida Ayob, Jamaludin Mohamad and Khanom Simarani \\ Institute of Biological Sciences, Faculty of Science, University of Malaya, Kuala Lumpur, Malaysia
}

\begin{abstract}
Four endophytic fungi have been tested for antioxidant properties using different assays; DPPH radicalscavenging activity, ferric reducing antioxidant power (FRAP) and ferrous ion chelating activity (FCA). The test of polyphenolic content also has been done for both total phenolic content (TPC) and total flavonoid content (TFC). There was no result on the half maximal concentration $\left(\mathrm{IC}_{50}\right)$ for both DPPH and FCA assays for all fungi. However, through FRAP assays the results were ranged from $0.336 \pm 0.01$ to $0.477 \pm 0.11 \mathrm{mmol} \mathrm{Fe}{ }^{2+} / \mathrm{g}$ extract where $N$. sphaerica had the highest result. This fungus also showed the highest results on TPC and TFC, which were $0.030 \pm 0.000(\mathrm{mg} \mathrm{GAE} / \mathrm{g})$ and $0.038 \pm 0.001(\mathrm{mg} \mathrm{QE} / \mathrm{g})$ respectively.
\end{abstract}

Keywords: Filamentous fungi, crude fungal extract, DPPH, TPC, TFC.

\section{INTRODUCTION}

Antioxidant is defined as a compound that can delay, inhibit or prevent the antioxidant of oxidizable materials through scavenging free radicals and diminishing oxidative stress [1]. This is supported by Halliwell et al. [2] from their report that antioxidant is any substances that present antitumour at low concentration compared to those of an oxidizable substrate significantly delays or prevents oxidation of that substrate. The mechanism of this antioxidant compound is by associating with decreased DNA damage; diminished lipid peroxidation maintained immune functions and inhibited malignant transformation of cells [3]. Antioxidant properties can be determined by using a few methods such as DPPH scavenging activities, ferric reducing antioxidant power and ferrous chelating activities. However, DPPH scavenging activity is the most popular method to determine the antioxidant properties since it is a simple method [4].

DPPH is a stable and nitrogen - centred free radical which produces violet colour in ethanol solution [5] with a chemical compound of $\mathrm{C}_{18} \mathrm{H}_{12} \mathrm{~N}_{5}$ $\mathrm{O}_{6}$. According to Huang et al. [4], by being a stable free radical, the DPPH assay is used to evaluate the ability of antioxidant to scavenge free radicals. It gives reliable evidence concerning the antioxidant ability of the tested compounds to act as free radical scavengers or hydrogen donors. It is supported by Yamagushi et al. [6] when DPPH free radicals become paired with hydrogen from a free radical scavenging antioxidant, its purple color fades rapidly to yellow to form reduced DPPH-H. Hence, it was reduced to a yellow coloured produced with the addition of the fractions in a concentration [5].

Thus, the studies on antioxidant activities are important for pharmaceutical industries. Part of that, the major groups of phytochemicals that have been suggested as a natural source of antioxidant may contribute to the total antioxidant activity of plant material, including polyphenols, carotenoid and traditional antioxidant vitamins such as vitamin $\mathrm{C}$ and E [7]. Phenolic is a compound possessing one or more aromatic rings with one or more hydroxyl groups [1] and has been considered as a powerful antioxidant in vitro and proved to be more potent antioxidant than vitamin $\mathrm{C}$, vitamin $\mathrm{E}$ and carotenoids [8] where natural phenolic can affect basic cell functions that related cancer development by many different mechanisms.

The mechanisms of phenolic compounds for antioxidant activities are neutralizing lipid free radicals and preventing decompositions of hydro peroxides into free radicals due to the presence of hydroxyl groups [5]. Thus, this study was about determination of antioxidant properties of endophytic fungi from $C$. roseus plant and phytochemical analysis of these endophytic fungi. 


\section{Antioxidants and Phytochemical Analysis of Endophytic Fungi Isolated from a Medicinal Plant Catharanthus roseus}

\section{MATERIALS AND METHODS}

\section{Samples preparation}

All fungi strains used in this project were previously isolated and identified by Ayob and Simarani [9]. The crude fungal extract has been prepared [10] and divided into crude mycelia extract (CME) and crude supernatant extract (CSE). Briefly, the cell free filtrate was extracted with a dichloromethane $(3 \times 200$ $\mathrm{ml}$ ) and evaporated to dryness using rotary evaporator. The extracted sample was weighed to constitute the CSE. Meanwhile, in order to prepared the CME, the mycelia biomass has been freeze-dried and extracted twice with a mixture of dichloromethane:methanol $(1: 1, \mathrm{v} / \mathrm{v})$ for $1 \mathrm{~h}$.

\section{Determination of polyphenolics content in the endophytic fungi}

\section{Total phenolic contents}

Total phenol content (TPC) was measured by the Folin-Ciocalteu method [11]. Briefly, $20 \mu \mathrm{L}$ of crude fungal extract (CFE) was mixed with $100 \mu \mathrm{L}$ of Folin-Ciocalteu reagent (diluted 10-fold with distilled water) in a 96-well microplate and incubated for 5 min before added with $75 \mu \mathrm{L}$ of sodium carbonate solution $(75 \mathrm{~g} / \mathrm{L})$. After $2 \mathrm{~h}$ incubated in darkness at room temperature, the absorbance was measured at $740 \mathrm{~nm}$ with a microplate reader (Tecan Sunrise, Austria). Tannic acid $(100-1000 \mu \mathrm{M})$ was used as a standard for calibration and construction of a linear regression line and water was used as a blank. The total phenolic content was estimated as mg tannic acid equivalent (mg TAE)/g of dry extract.

\section{Total flavonoid contents}

Total flavonoid content (TFC) was measured according to $[12,13]$. Briefly, $50 \mu \mathrm{L}$ of crude fungal extract (CFE) were added with $70 \mu \mathrm{L}$ of distilled water and $15 \mu \mathrm{L}$ of sodium nitrite solution $(5 \%)$ in a 96-well microplate. The solutions were well mixed and incubated at room temperature for $5 \mathrm{~min}$. Then, $15 \mu \mathrm{L}$ of aluminium chloride solution $(10 \%)$ was added into the mixture and incubated for $6 \mathrm{~min}$. Then, $100 \mu \mathrm{L}$ of $1 \mathrm{M}$ sodium hydroxide solution was added and the absorbance was measured at $510 \mathrm{~nm}$ with a microplate reader (Tecan Sunrise, Austria). The total flavonoid content (TFC) was estimated from quercetin $(200-1000 \mu \mathrm{M})$ standard curve and the results were expressed as $\mathrm{mg}$ quercetin equivalent (mg QE)/g of dry extract.

\section{Antioxidant activity assays DPPH radical scavenging activity}

The free radical scavenging activity of crude fungal extract (CFE) was measured in terms of hydrogen donating ability by using DPPH radical according to Margithas et al. [14] and Ablat et al. [13]. Briefly, 40 $\mu \mathrm{L}$ of crude fungal extracts with different concentrations $(0.05-2 \mathrm{mg} / \mathrm{mL})$ were mixed with $200 \mu \mathrm{L}$ of $50 \mu \mathrm{M}$ DPPH solution in methanol. Then, the mixture was immediately shaken before incubated in the dark at room temperature for $15 \mathrm{~min}$. The absorbance was measured at $517 \mathrm{~nm}$ with a micro plate reader (Tecan Sunrise, Austria). Butylated hydroxyanisole (BHA) with concentrations of $5-80 \mu \mathrm{g} / \mathrm{mL}$ was used as a standard while the control was ethanol. The percentage of inhibition activity of the extracts was calculated according to the following equation:

$$
\begin{gathered}
\text { DPPH radical scavenging activity }(\%) \\
=\left[\left(\mathrm{A}_{1}-\mathrm{A}_{2}\right) \times 100\right] / \mathrm{A}_{1}
\end{gathered}
$$

Where ,

$$
\begin{aligned}
& A_{1}=\text { Absorbance of control } \\
& A_{2}=\text { Absorbance of sample }
\end{aligned}
$$

The DPPH radical scavenging activity was estimated from the graph plotted against the percentage inhibition and compared with the standard in order to find the Half Maximal Inhibitory Concentration $\left(\mathrm{IC}_{50}\right)$.

\section{Ferric reducing antioxidant power}

The ferric reducing antioxidant power (FRAP) activities of crude fungal extracts were measured according to Muller et al. [11]. Briefly, $20 \mu \mathrm{L}$ of crude fungal extract (CFE) in methanol were mixed with $200 \mu \mathrm{L}$ of daily prepared ferric reducing antioxidant power (FRAP) reagent contained $5 \mathrm{~mL}$ of $10 \mathrm{mM}$ tripyridyl triazine (TPTZ) in $40 \mathrm{mM}$ hydrogen chloride ( $\mathrm{HCl}), 5 \mathrm{~mL}$ of $20 \mathrm{mM}$ iron (III) chloride $\left(\mathrm{FeCl}_{3}\right)$, and $50 \mathrm{~mL}$ of $0.3 \mathrm{M}$ acetate buffer; $\mathrm{pH} 3.6$ in 96-well microplate. The formation of the TPTZ-Fe ${ }^{2+}$ complex in the presence of antioxidant compounds in the extract was measured at $595 \mathrm{~nm}$ with a microplate reader (Tecan Sunrise, Austria) after incubating for $8 \mathrm{~min}$. Ferrous sulphate $\left(\mathrm{FeSO}_{4}\right)$ solution $(0.2-1 \mathrm{~mm})$ was used for a standard calibration curve while the methanol was used as blank. The ferric reducing antioxidant power (FRAP) value was evaluated according to the linear regression between standard solutions and 


\section{Antioxidants and Phytochemical Analysis of Endophytic Fungi Isolated from a Medicinal Plant \\ Catharanthus roseus}

absorbance at $595 \mathrm{~nm}$ and the results were estimated as $\mathrm{mmol} \mathrm{Fe}^{2+} / \mathrm{g}$ of dry extract from triplicated tests.

\section{Metal chelating activity}

Metal chelating activity or ferrous ion chelating activity (FCA) of the CFE was determined by measuring the formation of the ferrozine $\left(\mathrm{Fe}^{2+}\right)$ complex, according to the procedure described by Decker and Welch [15]. $10 \mu \mathrm{L}$ of extracts with different concentrations $(50-800 \mu \mathrm{g} / \mathrm{mL})$ were mixed with $120 \mu \mathrm{L}$ of distilled water and $10 \mu \mathrm{L}$ of 2 $\mathrm{mM}$ iron (II) chloride $\left(\mathrm{FeCl}_{2}\right)$ in a 96-well microplate. $20 \mu \mathrm{L}$ of $5 \mathrm{mM}$ ferrozine was added to the mixture in order to initiate the reaction. The reaction mixture was incubated for $20 \mathrm{~min}$ at room temperature and was measured at $562 \mathrm{~nm}$ along with EDTA-Na $_{2}(5-80 \mu \mathrm{g} / \mathrm{mL})$ as a standard metal chelator. $20 \mu \mathrm{L}$ of distilled water was used as a blank while $100 \mu \mathrm{L}$ of methanol was used as a control. The percentage of inhibition of ferrozine $\left(\mathrm{Fe}^{2+}\right)$ complex formation was calculated according to the following formula:

$$
\begin{gathered}
\text { Ferrous ion chelating activity }(\%) \\
=\left[\left(\underline{A}_{1}-\mathrm{A}_{2}\right) \times 100\right] / \mathrm{A}_{1}
\end{gathered}
$$

Where,

$$
\begin{aligned}
& A_{1}=\text { Absorbance of control } \\
& A_{2}=\text { Absorbance of sample }
\end{aligned}
$$

The metal chelating activity was estimated from the graph plotted against the percentage inhibition and compared with the standard in order to find the Half Maximal Inhibitory Concentration $\left(\mathrm{IC}_{50}\right)$.

\section{Statistical analysis}

All data were analysed by using analysis of variance (IBM SPSS Statistics, Version 20; IBM Corp., Armonk, New York) to determine the significant studies on antioxidant and polyphenolics compounds. The regression among variables was showed in surface plot graph.

\section{RESULTS AND DISCUSSION}

Total phenolic contents (TPC) of the crude fungal extract (CFE) were tested using Folin-Ciocalteu's reagent and expressed as Gallic acid equivalent ( $\mathrm{y}=$ $0.0042 \mathrm{x}+0.0196, \mathrm{r} 2=0.9996)$. While total flavonoid contents (TFC) were measured based on the equivalent of quercetin $(\mathrm{y}=0.0676 \mathrm{x}+0.0142, \mathrm{r} 2=$ 0.9997). The results showed that crude supernatant extract (CSE) of $N$. spherica had a higher value of both total phenolic contents (TPC) and total flavonoid contents (TFC), which were $0.030 \mathrm{mg}$ GAE/g and $0.038 \pm 0.001 \mathrm{QE} / \mathrm{g}$ respectively (Table 1). The lowest total phenolic contents (TPC) and total flavonoid contents (TFC) were crude mycelia extract (CME) of $N$. sphaerica (0.023 mg GAE/g) and CFE of C. gloeosporioides $(0.022 \pm 0.001 \mathrm{QE} / \mathrm{g})$ respectively.

According to Huang et al. [16], main natural products of secondary metabolites in plant and fungi were phenolic compounds where phenol and flavonoid compounds have been reported to possess different bioactivities. The antioxidant activity of crude fungal extracts was determined by using a methanol solution of DPPH reagent, ferric reducing antioxidant power (FRAP) and metal chelating activity (FCA). The percentage of DPPH radical scavenging activity ranged from $9.03 \%$ to $17.15 \%$ and $0.26 \%$ to $9.03 \%$ of mycelia and supernatant samples respectively (Table 2). However, there was no data for half maximal inhibitory concentration $\left(\mathrm{IC}_{50}\right)$ due to low scavenging activity.

The ferric reducing antioxidant power assay was measured based on the reaction between $\mathrm{Fe}^{3+}$-TPTZ and antioxidant potentials to form $\mathrm{Fe}^{2+}$-TPTZ in the fungi extract. The highest results showed that crude supernatant extract (CSE) of $N$. sphaerica produced $0.477 \pm 0.11 \mathrm{mmol} \mathrm{Fe}^{2+} / \mathrm{g}$ of extract while the lowest result was crude mycelia extract (CME) of $C$. gloeosporioides produced $0.336 \pm 0.01 \mathrm{mmol} \mathrm{Fe} \mathrm{F}^{2+} / \mathrm{g}$ of fungi extract (Table 3).

The metal chelating (FCA) activity was measured based on the chelation of ferrous ion with ferrozine and formed ferrous-ferrozine complex. The fungi extract were prepared in different concentrations (50$800 \mu \mathrm{g} / \mathrm{mL}$ ) (Table 4 and Figure 1). Through ferric reducing antioxidant assay, it showed that crude supernatant extract (CSE) of $N$. sphaerica has the highest result $0.477 \pm 0.11 \mathrm{mmol} \mathrm{Fe} \mathrm{Fe}^{2+} / \mathrm{g}$ of extract while crude mycelia extract (CME) of $C$. gloeosporioides has the lowest result $0.336 \pm 0.01$ $\mathrm{mmol} \mathrm{Fe} \mathrm{F}^{2+} / \mathrm{g}$ of extract (Table 5). 


\section{Antioxidants and Phytochemical Analysis of Endophytic Fungi Isolated from a Medicinal Plant}

Catharanthus roseus

Table 1. The polyphenolics content of crude fungal extracts

\begin{tabular}{|c|c|c|}
\hline Samples & TPC (mg GAE/g) & TFC (mg QE/g) \\
\hline $\mathrm{CG}(\mathrm{CME})$ & $0.024 \pm 0.001^{\mathrm{f}}$ & $0.022 \pm 0.002^{\mathrm{f}}$ \\
\hline $\mathrm{CG}(\mathrm{CSE})$ & $0.028 \pm 0.002^{\mathrm{c}}$ & $0.022 \pm 0.001^{\mathrm{f}}$ \\
\hline $\mathrm{MP}(\mathrm{CME})$ & $0.024 \pm 0.001^{\mathrm{f}}$ & $0.034 \pm 0.001^{\mathrm{b}}$ \\
\hline MP (CSE) & $0.027 \pm 0.001^{\mathrm{d}}$ & $0.023 \pm 0.001^{\mathrm{e}}$ \\
\hline NS (CME) & $0.023 \pm 0.000^{\mathrm{g}}$ & $0.025 \pm 0.002^{\mathrm{d}}$ \\
\hline NS (CSE) & $0.030 \pm 0.000^{\mathrm{a}}$ & $0.038 \pm 0.001^{\mathrm{a}}$ \\
\hline FS (CME) & $0.025 \pm 0.001^{\mathrm{e}}$ & $0.029 \pm 0.003^{c}$ \\
\hline $\mathrm{FS}$ (CSE) & $0.029 \pm 0.001^{\mathrm{b}}$ & $0.023 \pm 0.001^{\mathrm{e}}$ \\
\hline
\end{tabular}

Values presented are the means $\pm \mathrm{SD},(\mathrm{n}=3)$. Values within the same column and having different superscript letters are significantly different ( $\mathrm{p}<0.05)$. CG: C. gloeosporioides, MP: M. phaseolina, NS: N. sphaerica, FS: $F$. solani, TPC: total phenolic contents, TFC: total flavonoid contents, CME: crude mycelia extract and CSE: crude supernatant extract

Table 2. The DPPH radical- scavenging activity of crude fungal extracts

\begin{tabular}{|c|c|c|c|c|c|c|c|c|c|c|}
\hline \multirow{3}{*}{$\begin{array}{l}\text { Concent } \\
\text { ration } \\
(\mu \mathrm{g} / \mathrm{mL})\end{array}$} & \multicolumn{10}{|c|}{ DPPH radical - scavenging activity (\%) } \\
\hline & \multicolumn{2}{|c|}{$\begin{array}{l}\text { C. } \\
\text { gloeosporioides }\end{array}$} & \multicolumn{2}{|c|}{ M. phaseolina } & \multicolumn{2}{|c|}{ N. sphaerica } & \multicolumn{2}{|c|}{ F. solani } & \multirow[t]{2}{*}{ VB } & \multirow[t]{2}{*}{ VC } \\
\hline & CME & CSE & CME & CSE & CME & CSE & CME & CSE & & \\
\hline \multirow[b]{2}{*}{50} & $20.73 \pm$ & $8.94 \pm$ & $26.49 \pm$ & $3.97 \pm$ & $9.52 \pm$ & $0.26 \pm$ & $10.75 \pm$ & $4.46 \pm$ & $17.57 \pm$ & $10.17 \pm$ \\
\hline & $0.15^{b}$ & $0.77^{\mathrm{f}}$ & $0.15^{\mathrm{a}}$ & $0.26^{\mathrm{b}}$ & $0.69^{\mathrm{e}}$ & $0.02^{\mathrm{h}}$ & $0.90^{\mathrm{d}}$ & $0.38^{\mathrm{g}}$ & $0.83^{c}$ & $0.86^{\mathrm{d}}$ \\
\hline \multirow{3}{*}{100} & $4.99 \pm$ & $9.37 \pm$ & $16.98 \pm$ & $9.44 \pm$ & $9.03 \pm$ & $0.26 \pm$ & $9.86 \pm$ & $8.42 \pm$ & $9.73 \pm$ & $8.47 \pm$ \\
\hline & $0.42^{\mathrm{d}}$ & $0.80^{\mathrm{b}}$ & $0.74^{\mathrm{a}}$ & $0.74^{\mathrm{b}}$ & $0.65^{b}$ & $0.02^{\mathrm{e}}$ & $0.83^{b}$ & $0.72^{\mathrm{c}}$ & $0.78^{b}$ & $0.71^{\mathrm{c}}$ \\
\hline & $9.19 \pm$ & $7.76 \pm$ & $20.82 \pm$ & $10.12 \pm$ & $16.80 \pm$ & $9.03 \pm$ & $10.14 \pm$ & $8.29 \pm$ & $24.89 \pm$ & $18.76 \pm$ \\
\hline 150 & $0.75^{\mathrm{f}}$ & $0.67^{\mathrm{h}}$ & $0.20^{\mathrm{b}}$ & $0.79^{\mathrm{e}}$ & $0.64^{\mathrm{d}}$ & $0.40^{\mathrm{f}}$ & $0.85^{\mathrm{e}}$ & $0.71^{\mathrm{g}}$ & $0.39^{\mathrm{a}}$ & $0.81^{\mathrm{c}}$ \\
\hline \multirow[b]{2}{*}{200} & $15.75 \pm$ & $7.84 \pm$ & $19.22 \pm$ & $8.91 \pm$ & $17.15 \pm$ & $0.26 \pm$ & $9.73 \pm$ & $7.68 \pm$ & $29.05 \pm$ & $24.06 \pm$ \\
\hline & $0.67^{\mathrm{e}}$ & $0.67^{\mathrm{h}}$ & $0.84^{\mathrm{c}}$ & $0.69^{\mathrm{g}}$ & $0.64^{\mathrm{d}}$ & $0.02^{\mathrm{i}}$ & $0.81^{\mathrm{f}}$ & $0.66^{\mathrm{h}}$ & $0.23^{\mathrm{a}}$ & $0.42^{\mathrm{b}}$ \\
\hline \multirow[b]{2}{*}{250} & $8.83 \pm$ & $13.39 \pm$ & $25.53 \pm$ & $11.21 \pm$ & $10.29 \pm$ & $0.26 \pm$ & $15.85 \pm$ & $8.16 \pm$ & $24.98 \pm$ & $24.22 \pm$ \\
\hline & $0.72^{\mathrm{g}}$ & $0.59^{d}$ & $0.08^{a}$ & $0.45^{\mathrm{e}}$ & $0.76^{\mathrm{f}}$ & $0.02^{\mathrm{h}}$ & $0.71^{\mathrm{g}}$ & $0.70^{\mathrm{h}}$ & $0.36^{\mathrm{b}}$ & $0.44^{\mathrm{b}}$ \\
\hline
\end{tabular}

Values presented are the means $\pm \mathrm{SD},(\mathrm{n}=3)$. Values within the same row and having different superscript letters are significantly different ( $\mathrm{p}$ < 0.05).CG: C. gloeosporioides, MP: M. phaseolina, NS: N. sphaerica, FS: F. solani, VB: Vinblastine, VC: Vincristine, CME: crude mycelia extract, CSE: crude supernatant extract and BHA: Butylatedhydroxyanisole

Table 3. Ferric reducing antioxidant power (FRAP) of crude fungal extracts

\begin{tabular}{cc}
\hline Samples & $\begin{array}{c}\text { Ferric reducing antioxidant power } \\
\left(\mathbf{m m o l ~ F e} \mathbf{~}^{\mathbf{2 +}} / \mathbf{g} \text { extract }\right)\end{array}$ \\
\hline CG (CME) & $0.336 \pm 0.01^{\mathrm{g}}$ \\
CG (CSE) & $0.400 \pm 0.04^{\mathrm{d}}$ \\
MP (CME) & $0.357 \pm 0.01^{\mathrm{e}}$ \\
MP (CSE) & $0.423 \pm 0.04^{\mathrm{c}}$ \\
NS (CME) & $0.347 \pm 0.01^{\mathrm{f}}$ \\
NS (CSE) & $0.477 \pm 0.11^{\mathrm{a}}$ \\
FS (CME) & $0.340 \pm 0.01^{\mathrm{f}}$ \\
FS (CSE) & $0.437 \pm 0.11^{\mathrm{b}}$ \\
VC & $0.103 \pm 0.01^{\mathrm{h}}$ \\
FeSO & $0.097 \pm 0.01^{\mathrm{i}}$ \\
\hline
\end{tabular}

Values presented are the means $\pm \mathrm{SD},(\mathrm{n}=3)$. Values within the same raw and having different superscript letters are significantly different ( $\mathrm{p}$ < 0.05). CG: C. gloeosporioides, MP: M. phaseolina, NS: N. sphaerica, FS: F. solani, VB: Vinblastine, VC: Vincristine, CME: crude mycelia extract, CSE: crude supernatant extract and FeSO $\mathrm{S}_{4}$ Ferrous sulphate 
Antioxidants and Phytochemical Analysis of Endophytic Fungi Isolated from a Medicinal Plant Catharanthus roseus

Table 4. Metal chelating activity (FCA) of crude fungal extracts

\begin{tabular}{|c|c|c|c|c|c|}
\hline \multirow[t]{3}{*}{ Samples } & \multicolumn{5}{|c|}{ Metal chelating activity $(\%)$} \\
\hline & \multicolumn{5}{|c|}{ Concentration $(\mu \mathrm{g} / \mathrm{mL})$} \\
\hline & 50 & 100 & 200 & 400 & 800 \\
\hline $\mathrm{CG}(\mathrm{CME})$ & $20.48 \pm 0.87^{\mathrm{h}}$ & $17.92 \pm 0.63^{\mathrm{h}}$ & $27.55 \pm 0.78^{f}$ & $18.01 \pm 0.64^{\mathrm{g}}$ & $16.53 \pm 0.50^{i}$ \\
\hline $\mathrm{CG}(\mathrm{CSE})$ & $38.86 \pm 0.05^{\mathrm{d}}$ & $37.85 \pm 0.14^{\mathrm{c}}$ & $39.16 \pm 0.01^{\mathrm{b}}$ & $37.07 \pm 0.06^{\mathrm{c}}$ & $37.78 \pm 0.13^{c}$ \\
\hline $\mathrm{MP}(\mathrm{CME})$ & $20.76 \pm 0.50^{h}$ & $18.65 \pm 0.73^{\mathrm{g}}$ & $12.33 \pm 0.13^{\mathrm{i}}$ & $18.47 \pm 0.72^{\mathrm{g}}$ & $21.51 \pm 0.55^{\mathrm{h}}$ \\
\hline MP (CSE) & $24.44 \pm 0.59^{a}$ & $18.96 \pm 0.70^{\mathrm{g}}$ & $18.33 \pm 0.64^{\mathrm{g}}$ & $18.67 \pm 0.67^{\mathrm{g}}$ & $23.61 \pm 0.58^{\mathrm{g}}$ \\
\hline NS (CME) & $37.25 \pm 0.10^{\mathrm{e}}$ & $30.80 \pm 0.44^{\mathrm{d}}$ & $32.16 \pm 0.21^{\mathrm{d}}$ & $28.87 \pm 0.63^{\mathrm{e}}$ & $27.08 \pm 0.75^{\mathrm{e}}$ \\
\hline NS (CSE) & $34.42 \pm 0.22^{\mathrm{f}}$ & $23.34 \pm 0.66^{\mathrm{e}}$ & $30.64 \pm 0.36^{\mathrm{e}}$ & $29.58 \pm 0.29^{\mathrm{d}}$ & $26.66 \pm 0.78^{f}$ \\
\hline $\mathrm{FS}(\mathrm{CME})$ & $39.72 \pm 0.15^{\mathrm{c}}$ & $30.59 \pm 0.75^{\mathrm{d}}$ & $38.31 \pm 0.12^{\mathrm{c}}$ & $29.06 \pm 0.88^{\mathrm{d}}$ & $32.44 \pm 0.50^{\mathrm{d}}$ \\
\hline FS (CSE) & $24.41 \pm 0.66^{\mathrm{g}}$ & $19.06 \pm 0.79^{f}$ & $15.78 \pm 0.28^{\mathrm{h}}$ & $25.79 \pm 0.49^{f}$ & $26.26 \pm 0.47^{f}$ \\
\hline VB & $95.97 \pm 0.03^{\mathrm{a}}$ & $94.38 \pm 0.03^{b}$ & $93.18 \pm 0.05^{\mathrm{a}}$ & $91.02 \pm 0.04^{\mathrm{b}}$ & $89.55 \pm 0.02^{b}$ \\
\hline $\mathrm{VC}$ & $97.50 \pm 0.03^{b}$ & $95.27 \pm 0.00^{\mathrm{a}}$ & $93.91 \pm 0.01^{\mathrm{a}}$ & $92.52 \pm 0.05^{\mathrm{a}}$ & $92.41 \pm 0.05^{\mathrm{a}}$ \\
\hline EDTA-Na 2 & $98.29 \pm 0.11^{\mathrm{a}}$ & $93.71 \pm 0.05^{\mathrm{c}}$ & $88.11 \pm 0.15^{\mathrm{b}}$ & $83.31 \pm 0.09^{c}$ & $77.59 \pm 0.02^{\mathrm{c}}$ \\
\hline
\end{tabular}

Values presented are the means $\pm \mathrm{SD},(\mathrm{n}=3)$. Values within the same row and having different superscript letters are significantly different ( $\mathrm{p}$ 0.05). CG: C. gloeosporioides, MP: M. phaseolina, NS: N. sphaerica, FS: F. solani, VB: Vinblastine, VC: Vincristine, CME: crude mycelia extract and CSE: crude supernatant extract

Table 5: Antioxidant and phytochemical analysis of crude fungal extracts

\begin{tabular}{|c|c|c|c|c|c|}
\hline Samples & $\begin{array}{c}\text { DPPH } \\
\left(\mathrm{IC}_{50}\right. \\
\mu \mathrm{g} / \mathrm{mL})\end{array}$ & $\begin{array}{c}\text { FRAP } \\
\left(\mathrm{mmol} \mathrm{Fe}^{2+} / \mathrm{g} \text { extract }\right)\end{array}$ & $\begin{array}{c}\text { FCA } \\
\left(\mathrm{IC}_{50} \mu \mathrm{g} / \mathrm{mL}\right)\end{array}$ & $\begin{array}{c}\text { TPC } \\
\text { (mg GAE/g) }\end{array}$ & $\begin{array}{c}\text { TFC } \\
(\mathrm{mg} \mathrm{QE} / \mathrm{g})\end{array}$ \\
\hline $\mathrm{CG}(\mathrm{CME})$ & ND & $0.336 \pm 0.01^{\mathrm{g}}$ & ND & $0.024 \pm 0.001^{\mathrm{f}}$ & $0.022 \pm 0.002^{\mathrm{f}}$ \\
\hline CG (CSE) & ND & $0.400 \pm 0.04^{\mathrm{d}}$ & ND & $0.028 \pm 0.002^{c}$ & $0.022 \pm 0.001^{\mathrm{f}}$ \\
\hline MP (CME) & ND & $0.357 \pm 0.01^{\mathrm{e}}$ & ND & $0.024 \pm 0.001^{\mathrm{f}}$ & $0.034 \pm 0.001^{\mathrm{b}}$ \\
\hline MP (CSE) & ND & $0.423 \pm 0.04^{\mathrm{c}}$ & ND & $0.027 \pm 0.001^{\mathrm{d}}$ & $0.023 \pm 0.001^{\mathrm{e}}$ \\
\hline NS (CME) & ND & $0.347 \pm 0.01^{\mathrm{f}}$ & ND & $0.023 \pm 0.000^{\mathrm{g}}$ & $0.025 \pm 0.002^{\mathrm{d}}$ \\
\hline NS (CSE) & ND & $0.477 \pm 0.11^{\mathrm{a}}$ & ND & $0.030 \pm 0.000^{\mathrm{a}}$ & $0.038 \pm 0.001^{\mathrm{a}}$ \\
\hline FS (CME) & ND & $0.340 \pm 0.01^{\mathrm{f}}$ & ND & $0.025 \pm 0.001^{\mathrm{e}}$ & $0.029 \pm 0.003^{\mathrm{c}}$ \\
\hline FS (CSE) & ND & $0.437 \pm 0.11^{\mathrm{b}}$ & ND & $0.029 \pm 0.001^{b}$ & $0.023 \pm 0.001^{\mathrm{e}}$ \\
\hline VB & ND & $0.103 \pm 0.01^{\mathrm{h}}$ & $22.00^{\mathrm{a}}$ & - & - \\
\hline $\mathrm{VC}$ & ND & $0.097 \pm 0.01^{\mathrm{i}}$ & $22.00^{\mathrm{a}}$ & - & - \\
\hline
\end{tabular}

Data are mean \pm SD $(n=3)$. Values within the same row and having different superscript letters are significantly different ( $\mathrm{p}>0.05)$. DPPH: diphenyl-1-picrylhydrazyl, FRAP: ferric reducing antioxidant power, FCA: ferrous ion chelating activity, TPC: total phenolic content, TFC: total flavonoid content, ND: not detected, CG: $C$.

gloeosporioides, MP: M. phaseolina, NS: N. sphaerica, FS: F. solani, VB: Vinblastine, VC: Vincristine, CME: crude mycelia extract and CSE: crude supernatant extract. 
Table 6. The ANOVA of antioxidant and polyphenolic content on endophytic fungi from C. roseus

\begin{tabular}{|c|c|c|c|c|}
\hline & \multicolumn{4}{|c|}{ Regression } \\
\hline & Sum of Squares & Mean Square & $\mathbf{F}$ & Sig. \\
\hline Fungi & 0.000 & 0.000 & 0.011 & 0.919 \\
\hline Fungi*CFE & 0.006 & 0.003 & 0.089 & 0.915 \\
\hline \multirow[t]{3}{*}{ Fungi*CFE*Test } & 0.532 & 0.177 & 18.637 & 0.000 \\
\hline & \multicolumn{4}{|c|}{ Correlation } \\
\hline & Sum of Squares & Pearson Correlation & $\begin{array}{c}\text { Sig. } \\
\text { (1-tailed) }\end{array}$ & $\begin{array}{c}\text { Sig. } \\
\text { (2-tailed) }\end{array}$ \\
\hline Fungi & 0.102 & 0.022 & 0.459 & 0.919 \\
\hline $\mathrm{CFE}$ & 0.186 & 0.089 & 0.339 & 0.679 \\
\hline Test & -2.901 & -0.853 & $0.000 * *$ & $0.000 * *$ \\
\hline
\end{tabular}

Fungi (CG, MP, NS, FS); CFE (CME, CSE); Test (Antioxidant, TPC, TFC)

$* *$ correlation was significant at the 0.01 levels.

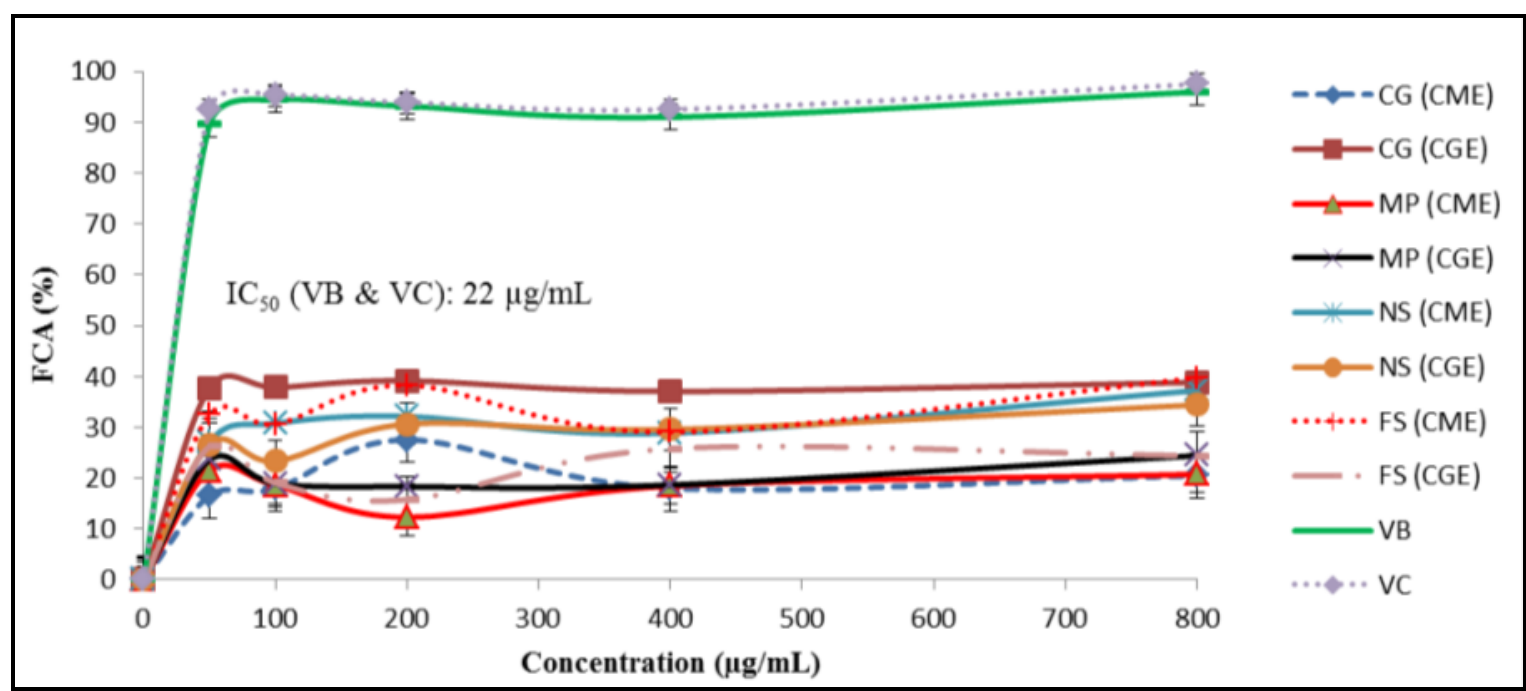

Figure 1. The antioxidant assay of crude fungal extracts from $C$. roseus plant by using ferrous ion chelating activity (FCA) at $562 \mathrm{~nm}$. CG: C. gloeosporioides, MP: M. phaseolina, NS: N. sphaerica, FS: F. solani, VB: Vinblastine, VC: Vincristine, CME: crude mycelia extract and CSE: crude supernatant extract

This analysis also revealed that crude supernatant extract (CSE) of $N$. sphaerica has the highest properties for both antioxidant and polyphenolic; total phenolic content (TPC) and total flavonoid content (TFC). According to Ablat et al. [13], the extract containing the high value of total phenolic content and total flavonoid content showed the highest reducing power activity. The ferric reducing ability correlated well with total phenolic content (r2 $=0.9996)$, total flavonoid content $(\mathrm{r} 2=0.997)$ contents in the fraction and this was supported by Velioglr et al. [17] from their report that the antioxidant activity of plant material is very well correlated with the content of phenolic compounds. The most significant studies on antioxidant and polyphenolics compounds were determined using an analysis of variance (ANOVA). Table 6 showed the regression of fungi*crude fungal extract*test was significantly different. Besides, the correlation among test was also significant at the 0.01 level.

\section{CONCLUSION}

$N$. sphaerica isolated from a medicinal plant $C$. roseus has potential as an antioxidant agent due to the significant result on both antioxidant and polyphenolic properties compared to the other species. Since there was no result on $\mathrm{IC}_{50}$ of $\mathrm{DPPH}$ radical - scavenging activity and $\mathrm{IC}_{50}$ of ferrous ion chelating activity, the data on ferric reducing antioxidant power was used as a comparison to a polyphenolic property. From the analysis, all CSE showed the highest result on the antioxidant properties through ferric reducing antioxidant power 


\section{Antioxidants and Phytochemical Analysis of Endophytic Fungi Isolated from a Medicinal Plant \\ Catharanthus roseus}

(FRAP) assay compared to crude mycelia extract (CME) of each endophytic fungi and this also applied to the total phenolic content (TPC) analysis. Thus, as a summary, the crude supernatant extract (CSE) samples were more productive on antioxidant and polyphenolic assays. Meanwhile, N. sphaerica has a great potential as the antioxidant agents and also could produce the polyphenolic compounds.

\section{ACKNOWLEDGEMENT}

The authors would like to acknowledge the Ministry of Higher Education (MOHE) for the scholarship of Farah Wahida Ayob during this study. This research was sup-ported by the University of Malaya for research grants IPPP (PG032-2012B) and UMRG project (UMRG048-11BIO).

\section{REFERENCES}

[1] Dai, J. and Mumper, R.J., 2010. Plant phenolics: extraction, analysis and their antioxidant anticancer properties. Molecules, 15: 7313-7352. doi: 10.3390/molecules 15107313.

[2] Halliwell, B., Aeschbach, R., Ltliger, J. and Aruoma, O.I., 1995. The characterization of antioxidants. Food and Chemical Toxicology, 33: 601-617.

[3] Gropper, S.S., Simmons, K.P., Gaines, A., Drawdy, K., Saunders, D., Ulrich, P. and Connell, L.J., 2009. The freshman 15- a closer look. Journal of American College Health, 58(3): 223-231.

[4] Huang, D., Ou, B., Prior, R.L., 2005. The chemistry behind antioxidant capacity assays. Journal of Agricultural Food Chemistry, 53: 1841-1856.

[5] Pushpalatha, K.C., Murthy, N.K. and Joshi, C.G., 2011. Antioxidant activity and phytochemical analysis of endophytic fungi isolated from Lobelia nicotianifolia. Journal of Chemical and Pharmaceutical Research, 3(5): 218-225.

[6] Yamagishi, T., Takamura, H., Matoba, T. and Terao, J., 1998. HPLC method for evaluation of the free radical scavenging activity of foods by using 1, 1,-diphenyl-2-pierylhydrazyl. Bioscience, Biotehcnology and Biochemistery, 62: 1201-1204.
[7] Maisarah, A.M., Nurul Amira, B., Asmah, R. and Fauziah, O., 2013. Antioxidant analysis of different parts of Carica papaya. International Food Research Journal, 20(3): 1043-1048.

[8] Rice-Evans, C.A., Miller, N.J. and Paganga, G., 1996. Structure-antioxidant activity relationships of flavonoids and phenolic acids. Free Radical Biology \& Medicine, 20: 933-956.

[9] Ayob, F.W. and Simarani, K. 2016. Endophytic filamentous fungi from Catharanthus roseus: Identification and its hydrolytic enzymes. Saudi Pharmaceutical Journal, 24(3): 273-278.

[10] Ayob, F.W., Simarani, K., Zainal, A.N. and Mohamad, J. 2017. First report on Nigrospora sphaerica isolated from Catharanthus roseus plant with an anticarcinogenic properties. Microbial Biotechnology 10(4): 926-932

[11] Muller, L., Gnoyke, S., Popken, A.M., Bohm, V., 2010. Antioxidant capacity and related parameters of different fruit formulations. Food Science \& Technology, 43(6): 992-999.

[12] Sasipriya, G. and Siddhuraju, P., 2012. Effect of different processing methods on antioxidant activity of underutilized legumes, Entada scandens seed kernel and Canavalia gladiate seeds. Food and Chemical Technology, 50(8): 2864-2872.

[13] Ablat, A., Mohamad, J., Awang, K., Shilpi, J.A. and Arya, A., 2014. Evaluation of antidiabetic and antioxidant properties of Brucea javanica seed. The Scienctific World Journal.

[14] Marghitas, L.A., Stanciu, O.G. and Dezmerian, D.S., 2009. In vitro antioxidant capacity of honeybee-collected pollen of selected floral origin harvested from Romania. Food Chemistry, 115(3): 878-883.

[15] Decker, E.A. and Welch, B., 1990. Role of ferritin as a lipid oxidation catalyst in muscle food. Journal of Agricultural and Food Chemistry, 38(3): 674-677.

[16] Huang, W.Y., Cai, Y.Z. and Zhang, Y., 2010. Natural phenolic compounds from medicinal herbs and dietary plants: Potential use for cancer prevention. Nutritioan \& Cancer, 62(1): 1-20.

[17] Velioglu, Y.S., Mazza, G. and Oomah, B.D., 1998. Antioxidant activity and total phenolics in selected fruits, vegetables and grain products. Journal of Agricultural and Food Chemistry, 46: 4113-4117. 